\title{
Edukasi Manajemen Kesehatan Remaja Saat Menstruasi di SMP N 5 Kota Jambi
}

\author{
Nel Efni ${ }^{1}$, Tina Yuli Fatmawati ${ }^{2}$ \\ ${ }^{1}$ Program Studi S-I Keperawatan, STIKes Baiturrahim Jambi \\ ${ }^{2}$ Program Studi DIII Keperawatan, STIKes Baiturrahim Jambi \\ Email: nelefni2016@gmail.com
}

Submitted : 12/06/2021

Accepted: 14/06/2021

Published: 28/06/2021

\begin{abstract}
The obligation to maintain health and hygiene related to menstruation is almost ignored by many people. Many factors that cause it, can be due to ignorance or due to lack of education from schools and parents. Many girls do not have a proper understanding that their menstruation is a normal biological process and they only know it at menarche. Insufficient knowledge about menstruation, menstrual cycle and Menstrual Hygiene Management (MKM) during menstruation can result in problems during menstruation such as dysmenorrhea, pelvic muscle cramps. This community service was carried out at the SMP N 5 Jambi City, with the aim that students could understand how to maintain cleanliness during menstruation. so that adolescents will be free from diseases, especially those related to reproductive health. The service method applied by the community service team is discussion, guidance, and persuasive communication. Held in December 2020-January 2021. After the counseling activities were carried out, all the teenagers who attended understood about treatment during menstruation
\end{abstract}

Keywords: health education, menstruation, students

\begin{abstract}
Abstrak
Kewajiban menjaga kesehatan dan kebersihan terkait menstruasi hampir diabaikan oleh banyak orang. Banyak faktor yang menyebabkannya, bisa karena ketidaktahuan atau karena kurangnya edukasi dari sekolah maupun orang tua. Banyak anak perempuan tidak memiliki pemahaman yang tepat bahwa menstruasi mereka adalah proses biologis yang normal dan mereka justru baru mengenalnya pada saat menarke. Ketidakcukupan pengetahuan tentang menstruasi, siklus menstruasi dan Manajemen Kebersihan Menstruasi (MKM) saat menstruasi ini dapat berakibat masalah selama menstruasi seperti dysminore, kram otot panggul. Pengabdian masyarakat ini dilaksanakan di SMP N 5 Kota Jambi terletak di Jln Prom M Yamin SH, dengan tujuan siswi dapat memahami tentang bagaimana menjaga kebersihan saat menstruasi. sehingga remaja akan terbebas dari penyakit khususnya yang berkaitan dengan kesehatan reproduksi. Metode pengabdian yang diterapkan oleh tim pengabdian masyarakat adalah diskusi, Pembimbingan, komunikasi persuasif . Dilaksanakan pada bulan Desember 2020- Januari 2021. Setelah dilakukan kegiatan penyuluhan semua remaja yang hadir memahami tentang perawatan saat mentruasi.
\end{abstract}

Kata Kunci : pendidikan kesehatan, menstruasi, siswi.

\section{PENDAHULUAN}

Kesehatan menstruasi merupakan salah satu aspek penting dalam membangun kualitas sumber daya manusia dan berkaitan erat dengan kesehatan reproduksi. Permasalahan seputar menstruasi seringkali dianggap tabu untuk dibahas di ranah publik dan kurang mendapat perhatian 
untuk dipelajari dan diajarkan, khususnya kepada perempuan. Hal tersebut antara lain yang menyebabkan masih tersebarnya mitos seputar menstruasi dan persepsi yang tidak tepat berkaitan dengan menstruasi.(Sinaga, 2017).

Menstruasi adalah keadaan yang normal, yang akan dialami oleh setiap perempuan yang normal kesehatannya. Tetapi pada saat menstruasi dapat terjadi beberapa hal yang mungkin dapat mencemaskan diri kita ataupun keluarga. Walaupun tidak semua perempuan akan mengalami hal yang sama, namun beberapa gangguan atau perubahan keadaan ketika menstruasi adalah normal. Namun demikian, kalau dibiarkan begitu saja, apalagi kita tidak mengerti, tidak mempunyai ilmu tentang hal tersebut, gangguan tersebut mungkin akan semakin parah. Akan tetapi kalau kita memahaminya dan tahu cara mengatasinya, maka kemungkinan besar gangguan tersebut akan menjadi ringan sehingga tidak akan mengganggu aktivitas kita sehari-hari.

Kewajiban menjaga kesehatan dan kebersihan terkait menstruasi hampir diabaikan oleh banyak orang. Banyak faktor yang menyebabkannya, bisa karena ketidaktahuan atau karena kurangnya perhatian dalam mengikuti apa yang seharusnya dilakukan. Saatnya masyarakat membiasakan hidup bersih dan sehat selama periode menstruasi dengan dukungan fasilitas yang memadai yang bukan hanya menjadi tanggung jawab kaum perempuan saja tetapi juga harus menjadi perhatian semua pihak utamanya di tempattempat umum seperti sekolah, mesjid, tempat wisata, rumah sakit, stasiun, pasar dan lainnya.
Ketidakcukupan air, fasilitas sanitasi, dan kebersihan di sekolah juga menjadi tantangan bagi remaja putri yang sedang menstruasi. Selain ketidakcukupan air untuk mencuci, toilet yang kecil dan tidak bersih serta kurangnya privasi menyebabkan remaja putri enggan unutuk mengganti pembalut di sekolah. Hampir semua fasilitas air, sanitasi dan kebersihan di sekolah tidak dapat diakses oleh siswa berkebutuhan khusus (cacat). Akibatnya, remaja putri terpaksa pulang kerumah untuk mengganti pembalut atau memakai kain selama lebih dari delapan jam dan itu dapat membuat alat kelamin iritasi dan gatal, juga mereka takut 'bocor' serta menodai pakaian, (Saribanon, 2016).

SMP N 5 Kota Jambi terletak di Jln Prom M Yamin SH, Kota Jambi. Memiliki siswi dengan latar belakang suku yang berbeda - beda. Dari survey yang telah dilakukan kepada salah satu siswi mengatakan masih belum memahami tentang bagaimana menjaga kebersihan saat menstruasi serta bagaimana mengurangi nyeri saat menstuasi. Oleh karena itu penting sekali remaja putri memiliki pengetahuan yang cukup berkaitan dengan kebiasaan /perawatan saat mentruasi sehingga remaja akan terbebas dari penyakit khususnya masalah kesehatan reproduksi...

\section{TARGET DAN LUARAN}

Target pada kegiatan ini adalah terjadinya peningkatan pengetahuan, pemahaman siswi SMP N 5 Kota Jambi dalam manajemen kesehatan saat menstruasi. Tersedianya Media KIE seperti leaflet dan poster tentang manajemen menstruasi. 


\section{METODE PELAKSANAAN}

Metode pengabdian yang akan diterapkan oleh tim pengabdian masyarakat adalah Ceramah, diskusi dan Tanya jawab, dilaksanakan pada bulan Januari 2021 bertempat di SMP N 5 Kota Jambi . Adapun pelaksanaannya dilaksanakan dalam beberapa tahap :

\section{Tahap Pertama}

Mengadakan Pertemuan dengan kepala sekolah dan guru BK/petugas UKS.

\section{Tahap Kedua}

Tahap ini metode yang digunakan ceramah, diskusi, tanya jawab dan pemberian media KIE tentang manajemen menstruasi. Kegiatan pengabdian dimasa pandemic Covid-19 ini, tim tidak bisa melaksanakan dengan mengumpulkan sejumlah siswi dalam jumlah banyak, sehingga tim mencari solusi selain memberikan edukasi secara langsung juga memberikan edukasi/ penyebaran leaflet melalui whatsapp kepada siswi dan melalui video confrence.

\section{Tahap Ketiga}

Pada tahap ketiga, dilakukan monitoring dan evaluasi kegiatan baik kepada siswi maupun guru BK.

\section{HASIL DAN PEMBAHASAN}

Kegiatan pengabdian masyarakat ini telah dilaksanakan pada hari Jum'at , 15 Januari 2021 diikuti oleh siswi -siswi SMP N 5 Kota Jambi melalui edukasi Daring/online. Kegiatan pemberian penyuluhan menggunakan aplikasi zoom meeting dengan menggunakan media Power point, Selama penyampaian materi para siswi sangat memperhatikan dengan baik dan antusias sekali ingin mengetahui manajemen kesehatan remaja saat menstruasi, karena selama ini terkadang mereka sering mendengar mitos mitos dan pantangan-pantangan ataupun persepsi yang tidak tepat yang berkaitan dengan mestruasi - Setelah selesai memberikan materi dibukalah sesi tanya jawab, beberapa siswi aktif bertanya, sehingga dapat dijelaskan sedetailnya kepada mereka supaya para siswi dapat memahami bagaimana cara memanag kesehatan saat menstruasi, sehingga tidak menimbulkan kecemasan mereka saat menstruasi dan mereka dapat mengaplikasikan pengetahuan ini agar terhindar dari prnyakit khususnya yang berkaitan dengan menstruasi

Menstruasi adalah perdarahan periodik dari rahim yang dimulai sekitar 14 hari setelah ovulasi secara berkala akibat terlepasnya lapisan endometrium uterus (Bobak, 2004). Jika seorang wanita tidak mengalami kehamilan, maka siklus menstruasi akan terjadi setiap bulannya. Umumnya siklus menstruasi pada wanita yang normal adalah 28-35 hari dan lama haid antara 3-7 hari. Siklus menstruasi pada wanita dikatakan tidak normal jika siklus haidnya kurang dari 21 hari atau lebih dari 35 hari.

Menjelang menstruasi pertama kali, remaja putri perlu dibekali dengan informasi yang memadai. Menstruasi merupakan peristiwa penting dalam kehidupan seorang remaja putri. Aspek kesehatan menstruasi merupakan bagian penting kesehatan reproduksi seorang perempuan, yang tidak hanya meliputi aspek kesehatan fisik, tetapi juga aspek kesehatanmental, spiritual maupun sosial. Seorang perempuan perlu mengetahui pola dan jarak dari menstruasi masing-masing, sehingga dapat menilai apabila terjadi hal di luar kebiasaan. (Sinaga,2017).

Kewajiban menjaga kesehatan dan kebersihan terkait menstruasi sering 
diabaikan. Faktor yang menyebabkannya antara lain karena ketidaktahuan atau karena kurangnya pengetahun, kurangnya edukasi disekolah atau petugas kesehatan. Oleh karena itu tim pengabdian telah berupaya memberikan edukasi dengan harapan siswi dapat memahami manajemen kesehatan saat menstruasi. Karena apabila menstruasi yang tidak terkelola dengan baik dapat menyebabkan, ketidakhadiran dalam kelas dan dapat mengalami masalah kesehatan reproduksi.

Salah satu manajemen kesehatan saat menstruasi adalah menjaga kebersihan tubuh, pakaian, olah raga secara teratur dan pengaturan asupan nutrisi
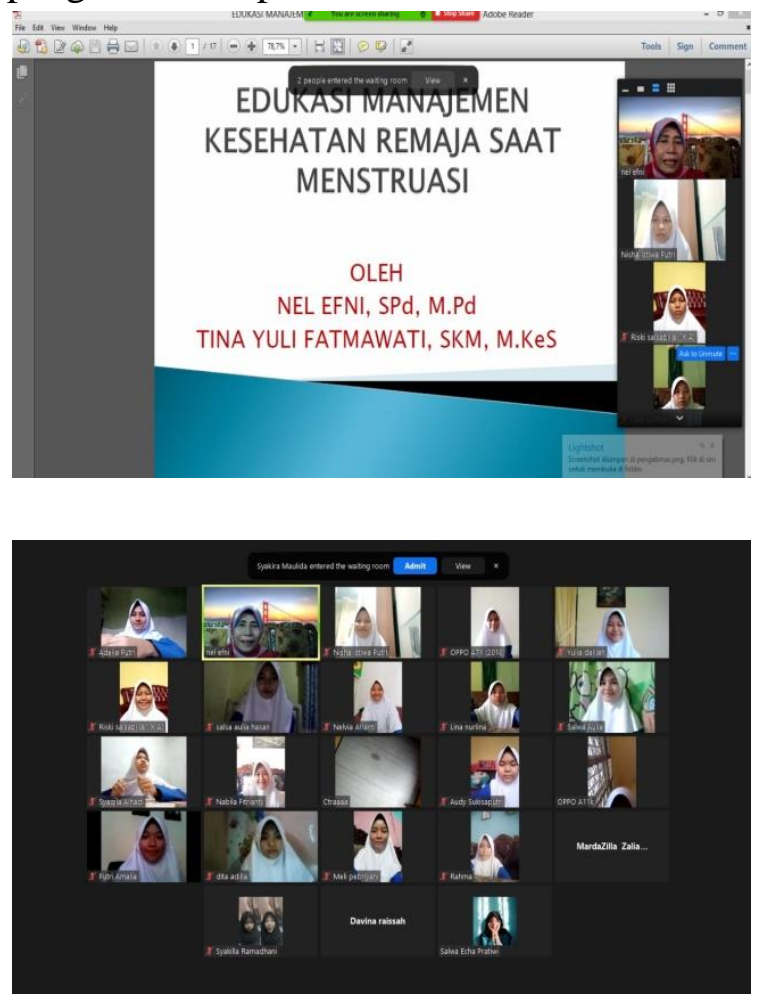

Gambar 1 dan 2. Pemberian edukasi pada siswi

\section{KESIMPULAN DAN SARAN}

\section{Kesimpulan}

Setelah dilakukan kegiatan edukasi, siswi yang hadir ( $100 \%)$ memahami tentang manajemen mentruasi sehingga remaja akan terbebas dari penyakit khususnya masalah yang sering terjadi saat menstruasi

\section{Saran}

Disarankan ke seluruh siswi SMP N 5 menambah pengetahuan dengan sering membaca buku maupun melalui media elektronik mengenai manajemen menstruasi , sehingga dapat meningkatkan pengetahuan serta dapat menerapkan dalam kehidupan sehari-hari.

\section{DAFTAR PUSTAKA}

Bobak, I.M. 2004. Keperawatan Maternitas. Alih Bahasa Maria A. Wijaya Rini.Edisi 4.Jakarta : EGC

Kemendikbud, 2017. Panduan Manajemen Kebersihan Menstruasi Bagi Guru Dan Orang tua. Indonesia

Saribanon dkk, 2017. Haid Dan Kesehatan menurut Ajaran Islam, Majelis Ulama Indonesia,Indonesia

Saribanon, 2016.Manajemen Kesehatan: Universitas Nasional:Indonesia

Sinaga, Ernawati dkk. 2017. Manajemen Kesehatan Universitas Nasional.

Global one 